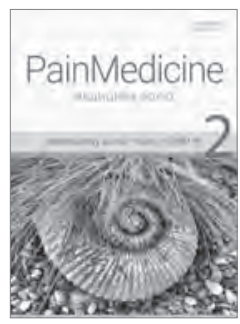

\title{
Влияние самостоятельной ишемической компрессии триггерных точек с помощью ролла у лиц с миофасциальным болевым синдромом
}

\author{
Гончаренко А. Ю. \\ Национальный университет физического воспитания и спорта Украины, г. Киев, Украина
}

Актуальность. Современный образ жизни, предполагающий низкую физическую активность, выполнение однотипных физических операций, высокий уровень психоэмоционального напряжения, длительное пребывание в сидячем положении, приводит к нарушениям осанки и жалобам на появление мышечных болей.

Влияние вышеперечисленных причин негативно сказывается на всех контингентах населения и требует использования в борьбе с ними всех средств, форм и методов физической реабилитации, физической культуры и спорта.

В общей популяции распространенность миофасциального болевого синдрома (МФБС) составляет $12 \%$, а среди лиц, обращающихся за медицинской помощью, достигает $30 \%$ (YарЕ.С., 2007). МФБС является наиболее частым патологическим состоянием опорнодвигательного аппарата (Иваничев Г. А., 1990).

Цель исследования. Изучить влияние самостоятельной ишемической компрессии триггерных точек с помощью ролла у лиц с миофасциальным болевым синдромом.

Материалы и методы. Теоретический анализ и обобщение специальной и научнометодической литературы, документов и информационных ресурсов сети Internet.

Результаты исследований и их обсуждение. Многие авторы отмечают положительное действие ишемической компрессии триггерных точек (ТT) с помощью кончиков паль- цев на МФБС (Simons D. G., Travell J. G., 1999; Шостак Н. А., Правдюк Н. Г., 2010).

Зарубежные авторы показывают, что влияние самостоятельной ишемической компрессии (СИК) на ТТ с помощью роллов и мячей разного диаметра имеют эффективное влияние в качестве дополнительного метода устранения боли в пояснице, спине и плечах при условии регулярного воздействия (Minyoung L., 2017).

Результаты, полученные другими исследователями, показывают, что постоянное применение специальной программы СИК на TT, которые развивают адекватное постепенно увеличивающееся давление с использованием роллов разного диаметра и плотности, может улучшить качество жизни людей с МФБС и при этом иметь положительные эффекты устранения или уменьшения боли (Ceca D., 2017).

Выводы. Несмотря на существующие исследования, многие авторы полагают, что необходимо провести дополнительные исследования аналогичного характера, чтобы подтвердить выводы, а также отмечают недостаточность исследований в данном направлении.

Перспективы дальнейших исследований. Разработка целостной программы воздействия на ТТ с помощью ролла и проведение педагогического эксперимента.

Ключевые слова: самостоятельная ишемическая компрессия, миофасциальный болевой синдром, триггерные точки.

Список литературы - в редакции. 